\title{
KEMAMPUAN MOTIVASI MEMODERASI PENGARUH KOMPETENSI, KEPEMIMPINAN DAN LINGKUNGAN KERJA PADA KINERJA BENDAHARA DESA DI KABUPATEN TABANAN
}

\author{
Nurhayati $^{1}$ \\ Ida Bagus Putra Astika ${ }^{2}$ \\ Made Gede Wirakusuma ${ }^{3}$ \\ ${ }^{1}$ Fakultas Ekonomi dan Bisnis Universitas Udayana, Bali, Indonesia \\ 1email: nurhayati433623@gmail.com \\ ${ }^{2}$ Fakultas Ekonomi dan Bisnis Universitas Udayana, Bali, Indonesia \\ ${ }^{3}$ Fakultas Ekonomi dan Bisnis Universitas Udayana, Bali, Indonesia
}

\begin{abstract}
ABSTRAK
Hasil penelitian terdahulu menyatakan bahwa kompetensi, kepemimpinan dan lingkungan kerja tidak selalu berpengaruh pada kinerja pegawai. Penelitian ini bertujuan untuk mengetahui kemampuan motivasi memoderasi pengaruh kompetensi, kepemimpinan dan lingkungan pada kinerja Bendahara Desa di Kabupaten Tabanan. Penelitian ini dilaksanakan pada seluruh Bendahara Desa di Kabupaten Tabanan dengan menggunakan data primer yang diperoleh dari kuesioner yang disebarkan kepada responden.Sampel dipilih adalah sampel jenuh sehingga diperoleh sebanyak 133 orang responden.Analisis data dilakukan dengan analisis Moderated Regression Analysis (MRA) yang didahului dengan uji validitas dan reliabilitas serta uji asumsi klasik.Hasil penelitian ini menunjukkan (1) motivasi tidak mampu memoderasi pengaruh kompetensi pada kinerja Bendahara Desa di Kabupaten Tabanan; (2) motivasi mampu memperkuat pengaruh kepemimpinan pada kinerja Bendahara Desa di Kabupaten Tabanan dan (3) motivasi tidak mampu memoderasi pengaruh lingkungan kerja pada kinerja Bendahara Desa di Kabupaten Tabanan.
\end{abstract}

Kata kunci : kompetensi, kepemimpinan, lingkungan kerja, motivasi, kinerja Bendahara Desa

\begin{abstract}
Results of previous studies stating that competence, leadership and work environment does not necessarily affect the performance of employees. This study aims to determine the ability to moderate the effect of competence motivation, leadership and environmental performance of Treasurer village in Tabanan.The research was conducted on the entire Treasurer village in Tabanan using primary data obtained from questionnaires distributed to respondents. The sample was selected is a saturated sample in order to obtain as many as 133 respondents. Data analysis was performed by analysis Moderated Regression Analysis (MRA), preceded by a test of validity and reliability and classic assumption test.The results showed (1) the motivation is not able to moderate the influence of competence in the performance of Treasurer village in Tabanan; (2) motivation to be able to strengthen leadership influence on the performance Treasurer village in Tabanan and (3) the motivation is not able to moderate the influence of the working environment on the performance Treasurer village in Tabanan.
\end{abstract}

Keywords: competence, leadership, work environment, motivation, performance Treasurer Village 


\section{LATAR BELAKANG}

Desa merupakan satuan terkecil dalam struktur pemerintahan di Indonesia. Pemerintah Indonesia telah menerbitkan secara formal Undang-undang (UU) Nomor 6 Tahun 2014 tentang Desa sebagai dasar hukum untuk mengatur segala sesuatu yang penting dalam penyelenggaraan Pemerintah Desa. Pembangunan desa diseluruh sektor kehidupan dilaksanakan bersama-sama dengan gotong royong dan swadaya masyarakat. dalam menyelenggarakan pemerintahan desa diberikan berbagai hak dan wewenang khusus untuk menentukan sikap dalam mengambil keputusan, menetapkan maupun mempertanggungjawabkan (Suwignjo, 1985:15). Hak, wewenang dan kewajiban berkembang dan tumbuh sejak desa tersebut dibentuk. Pembangunan desa merupakan seluruh kegiatan pembangunan yang berlangsung di pedesaan, meliputi seluruh aspek kehidupan sehari dalam masyarakat yang dilaksanakan secara terpadu dengan mengembangkan swadaya gotong royong.

Indikator keberhasilan pembangungan desa pada dasarnya adalah perbaikan riil dalam kondisi kehidupan masyarakat secara keseluruhan, karena pembangunan senatiasa merupakan proses perbaikan dari suatu proses keadaan ke keadaan yang lebih baik. Adanya paradigma pembangunan Desa telah mengalami perubahan konsep dan spirit dari era-era sebelumnya. Yakni, dari spirit "Membangun Desa" menjadi "Desa Membangun". "Desa Membangun" menempatkan desa sebagai subjek pembangunan, dimana Desa dapat merencanakan sendiri, melaksanakan sendiri, dan memberdayakan sendiri masyarakatnya. Sedangkan, pemerintah yang lebih tinggi bertugas memperkuat, 
memonitor dan mengawasi. Keberadaan Desa dimasa lalu hanya dijadikan sebagai obyek "penguasa". Keberadaan Desa dan masyarakatnya seolah-olah selalu lemah dan jauh dari sikap yang mandiri.

Pemberian Dana Desa langsung dari Anggaran Pendapatan dan Belanja Negara (APBN) untuk dikelola masyarakat desa adalah salah suatu bukti konkrit Pemerintahan untuk membangun dari pinggiran dan desa-desa. APBDes terdiri dari pendapatan, belanja dan pembiayaan Desa. Pendapatan desa yang dikelola bersama masyarakat desa bersumber dari (a) Pendapatan Asli Desa (PADes), (b) Transfer; dan(c) Pendapatan lain-lain. Dana Desa dan Alokasi Dana Desa merupakan pendapatan terbesar mereka jika dibandingkan dengan PADes sendiri. Desa-desa yang ada di KabupatTen Tabanan sebagian besar perekonomian bertumpu pada sektor pertanian, namum beberapa desa pada sektor perdagangan dan ada pula yang di sektor pariwisata. Dana Desa dan Alokasi Dana Desa merupakan pendapatan terbesar mereka jika dibandingkan dengan PADes sendiri. Penetapan prioritas Dana Desa, mengacu pada PP Nomor 60 tentang Dana Desa yang bersumber dari APBN, yang telah diubah menjadi PP Nomor 22 Tahun 2015. Dalam PP tersebut dijelaskan, bahwa mengingat Alokasi Dana Desa bersumber dari belanja pemerintah pusat, untuk mengoptimalkan penggunaan Dana Desa, pemerintah diberikan kewenangan untuk menetapkan prioritas penggunaan Dana Desa untuk mendukung program pembangunan Desa dan Pemberdayaan masyarakat Desa.

Pemerintah Desa sesuai UU no 6 Tahun 2014 tentang Desa adalah Kepala Desa atau Perbekel yang dibantu oleh Perangkat Desa (Sekretaris Desa, Kepala 
Seksi dan Bendahara).Dana Desa dan Alokasi Dana Desa merupakan pendapatan terbesar jika dibandingkan dengan PADes sendiri. Pemerintah memberikan kewenangan untuk menetapkan prioritas penggunaaan Dana Desa guna mendukung program pembangunan desa dan pemberdayaan masyarakat desa. Guna terwujudnya tata kelola yang baik (good governance) dalam penyelenggaraan desa, pengelolaan Keuangan Desa sesuai dengan Peraturan Menteri Dalam Negeri (Permendagri) Nomor 113 Tahun 2014 adalah semua hak dan kewajiban Desa yang dapat dinilai dengan uang serta segala sesuatu berupa uang dan barang yang berhubungan dengan pelaksanaan hak dan kewajiban desa, dan dalam tata kelola keuangan desa tetap menggacu pada prinsip transparan, akuntabel dan partisipatif serta dilakukan dengan tertib dan disiplin anggaran.Bendahara Desamempunyai tugas: menerima, menyimpan, menyetorkan/membayar, menatausahakan, dan mempertanggungjawabkan penerimaan pendapatan desa dan pengeluaran pendapatan desa dalam rangka pelaksanaan APBDes (Permendagri No 113 Tahun 2014).Sehubungan dengan penggunaan anggaran yang telah dikelola dari seluruh kegiatan program dicapai kualiatas dan kuantitas terukur merupakan kinerja Bendahara Desa.

Mengelola keuangan desa yang cukup besar membuat beberapa Bendahara Desa belum bisa melaksanakan tata kelola keuangan yang baik seperti transparan, akuntabel serta tertib administrasi. Laporan Hasil Pemeriksaan (LHP) BPK RI Perwakilan Provinsi Bali, Nomor: 29/LHP/XIX.DPS/12/2015, tanggal 31 Desember 2015 menyimpulkan bahwa: pemeriksaan BPK terhadap kinerja Bendahara Desa di 30 Desa yang menjadi sampel ditemukan beberapa 
penyimpangan sebagai berikut:(1) Pengelolaan penerimaan asli desa di luar mekanisme APBDes; (2) Buku pencatatan transaksi keuangan belum semua dibuat; (3) Pencatatan Buku Kas Umum (BKU) tidak tertib dan tidak sesuai dengan tanggal transaksi; (4) Bendahara menyimpan uang lebih dari 10 juta Rupiah. Terkait temuan BPK RI terhadap Dana Desa, kinerja seorang Bendahara Desa di Kabupaten Tabanan merupakan fenomena sangat menarik untuk diteliti.

Spencer dan Spencer (1993:41) menyatakan bahwa kompetensi adalah karakteristik dasar seseorang yang memengaruhi cara berpikir dan bertindak, membuat generalisasi terhadap segala situasi yang dihadapi, serta bertahan cukup lama dalam diri manusia.Kompetensiyang dimiliki seorang Bendahara Desa merupakan kemampuan yang dimiliki untuk bekerja sesuai dengan tujuan yang diinginkan organisasi. Kompetensi dapat meningkatkan kinerja Bendahara Desa karena dengan kompetensi tinggi berdampak pada kepercayaan diri dalam bekerja. Kompetensi yang dimaksud adalah pendidikan, pengalaman dan pelatihan. Pendidikan yang tinggi menyebabkan seorang pegawai mampu menyerap pengetahuan yang diterima, semakin lama menduduki posisi Bendahara Desa membuat pengalaman dalam menyelesaikan tugas akan lebih baik, cepat dan akurat. Banyaknya pelatihan yang diikuti Bendahara Desa akan membuat keterampilannya bertambah. Ketiga indikator tersebut dapat tercermin dari kompetensi karyawan yang dapat memotivasi dalam bekerja.

Kompetensi merupakan karakteristik pribadi yang mencakup perangai, konsep dan pengetahuan memprediksi tindakan-tindakan perilaku, keterampilan yang pada gilirannya akan memprediksi prestasi kerja. Adanya faktor motivasi 
diduga memperkuat atau memperlemah pengaruh kompetensi kinerja pegawai. Motivasi yang rendah menyebabkan seorang bendahara tidak dapat menatausahakan keuangan serta mempertanggungjawabkan dengan baik sehingga tujuan organisasi dalam menyejahterakan masyarakat tidak dapat terwujud dengan optimal.

Teori motivasi adalah salah satu bagian dari Goal Setting Theory seperti yang dikemukakan oleh Locke (1968) yang merupakan teori utama (grand theory) pada penelitian ini. Kaitan Goal Setting Theory adalah dalam penentuan tujuan keberhasilan organisasi adalah perencanaan yang baik sehingga dalam bertindak akan memengaruhi perilaku seseorang dalam suatu organisasi yang memiliki komitmen pada tujuan organisasi yang erat hubungannya dengan kinerja yang dihasilkan. Perencanan yang dimaksud dalam penelitian ini terdiri beberapa faktor diantaranya dalam rangka penunjukkan seorang Bendahara Desa adalah mempertimbangkan kompetensi, peran kepemimpinan juga berkaitan dengan kinerja Bendahara Desa, lingkungan kerja yang mendukung kelancaran tugas Bendahara Desa dan motivasi sebagai penyemangat agar Bendahara dapat bekerja maksimal. Penelitian ini menjelaskan beberapa faktor tersebut penentu sebagai keberhasilan Bendahara Desa dalam mencapai tujuan organisasi.

Kemampuan bekerja yang dimiliki sesuai dengan tujuan yang diinginkan organisasi merupakan kompetensi yang harus dimiliki seorang Bendahara Desa. Kompetensi disini meliputi pendidikan, pengalaman dan pelatihan. Pengetahuan akan banyak dapat diserap bila Bendahara Desa memiliki pendidikan yang tinggi, pengalaman dalam menyelesaikan tugas akan cepat, baik dan akurat ditentukan 
oleh lama menduduki posisi Bendahara Desa. Keterampilan Bendahara Desa akan bertambah sebanyak pelatihan yang diikuti.

Hasil penelitian terdahulu terkait kompetensi pegawai berpengaruh signifikan terhadap kinerja dinyatakan oleh: Emmayah (2009), Rahman, dkk (2014), Safwan, et al (2015), Suryadana, dkk (2014). Dhermawan, dkk (2012), Linawati dan Suhaji (2011) menunjukkan bahwa kompetensi berpengaruh signifikan terhadap kinerja pegawai. Ketidakkonsistenan hasil ini diduga ada variabel lain yang bertindak sebagai variabel moderasi sesusai dengan pendekatan kontijensi. Motivasi salah satu variabel moderasi yang memengaruhi hubungan kompetensi dengan kinerja pegawai. Berdasarkan penjabaran diatas dibuatlah suatu hipotesis:

$\mathrm{H}_{1}$ : Motivasi memperkuat pengaruh kompetensi pada kinerja Bendahara Desa di Kabupaten Tabanan.

Faktor lain yang memengaruhi kinerja Bendahara Desa adalah kepemimpinan. Kepemimpinan yang dilakukan oleh seorang atasan dapat dipersepsikan oleh setiap individu bersifat negatif atau positif. Persepsi yang berbeda-beda ini dipengaruhi faktor kebutuhan karyawan/bawahan. Bendahara Desa akan semangat dan bergairah dalam kerja bila atasan yang dijadikan panutan mereka memberikan contoh yang baik sehingga dapat meningkatkan kinerja dari Bendahara Desa.

Faktor lain yang menentukan kinerja pegawai atau keberhasilan organisasi adalah kepemimpinan. Inti dari kepemimpinan merupakan seni untuk mempengaruhi orang lain atau bawahan yang memiliki karakter berbeda-beda sehingga memiliki satu visi dan tujuan yang sama guna memajukan organisasi. 
Keberhasilan kepemimpinan dipengaruhi oleh komunikasi, memotivasi dan mengkoordinasikan organisasi dalam rangka mencapai tujuan. Kepemimpinan harus mampu membuat rasa percaya diri dan mendukung bawahan untuk bertindak dengan benar.

Teori kepemimpinan menurut Wursanto (2002:197) menguraikan bagaimana menjadi pemimpin yang baik menjadi: (1) Teori Kelebihan, menjabarkan 3 hal kelebihan seorang pemimpin yaitu kelebihan ratio, rohaniah dan kelebihan badaniah; (2) Teori Sifat, sifat positif yang dapat diikuti bawahannya seperti, inisiatif, energik, adil, melindungi dan komunikatif; (3) Teori Keturunan, pemimpin dapat diturunkan dari orangtua yang anaknya otomatis menjadi pemimpin; (4) Teori Kharismatik, kewibawaan merupakan daya tarik untuk mempengaruhi orang lain; (5) Teori Bakat, pemimpin dilahirkan karena bakat sejak lahir.

Pendekatan kontijensi digunakan peneliti dalam rangka memberikan masukan faktor-faktor yang sebaiknya dipertimbangkan dalam rangcangan penelitian. Motivasi merupakan variabel moderasi yang dimungkinkan dapat memperkuat ataupun memperlemah hubungan langsung antara variabel independen dan variabel dependen. Hal tersebut melihat dari beberapa ketidakkonsistenan dari beberapa penelitian. Penelitian yang menerangkan bahwa kepemimpinan berpengaruh pada kinerja pegawai antara lain: Suryadana, dkk (2014), Henarathgoda (2016), Thao, et al (2015), Jankingthong (2012), Munparidi (2012), Wahyuni (2015). Penelitian yang dilakukan oleh Sukmasari (2011), menyatakan kepemimpinan tidak berpengaruh signifikan terhadap kinerja 
karyawan. Suharyanto (2011) mengatakan bahwa secara simultan gaya kepemimpinan dan budaya organisasi berpengaruh signifikan terhadap kinerja pegawai. Rahman, dkk (2014) menunjukkan ada pengaruh signifikan kepemimpinan terhadap kinerja karyawan. Mujahidin (2013) menunjukkan bahwa gaya kepemimpinan tidak berpengaruh positif terhadap kinerja karyawan sedangkan motivasi berpengaruh positif terhadap kinerja karyawan. Penelitian lain mengatakan bahwa variabel kepemimpinan dan motivasi tidak berpengaruh signifikan terhadap kinerja karyawan Perusahaan Daerah Air Minum Tirta Musi Palembang (Munparidi, 2012).

Pemimpin yang lebih menekan bawahan/karyawan justru akan menurunkan kinerja karyawan. Kinerja merupakan capaian atau hasil kerja seseorang yang harus dicapai atau dapat dilaksanakan dalam kurun waktu tertentu. Pencapaian pelaksanaan suatu kegiatan atau program dapat diwujudkan dengan menetapkan tujuan, visi dan misi organisasi. Pemimpin dapat menuangkan rencana strategis dengan mengoptimalkan kinerja pegawainya.Berdasarkan perbedaan hasil penelitian tersebut terlihat ada perbedaan pengaruh kepemimpinan terhadap kinerja pegawai sehingga diduga ada faktor lain yang dapat memoderasi hubungan kepemimpinan dan kinerja adalah motivasi. Berdasarkan penjabaran diatas dibuatlah suatu hipotesis:

$\mathrm{H}_{2}$ : Motivasi memperkuat pengaruh kepemimpinan pada kinerja Bendahara Desa di Kabupaten Tabanan.

Lingkungan kerja yang kondusif juga dapat memengaruhi kinerja Bendahara Desa.Lingkungan kerja dapat dilihat dari lingkungan kerja fisik dan lingkungan kerja non fisik (Sedarmayanti; 2001). Segala sesuatu yang dapat 
dilihat secara fisik dan berada disekitar karyawan yang mampu memengaruhi baik secara langsung maupun tidak langsung merupakan lingkungan kerja fisik, diantaranya adalah suhu ditempat kerja, penerangan. Sirkulasi udara, dekorasi, keamanan disekitar wilayah kerja. Hubungan kerja yang baik antara atasan dengan bawahan, hubugan antar rekan kerja merupakan lingkungan kerja non fisik. Baiknya lingkungan kerja disekitar pegawai dapat memotivasi pegawai untuk meningkatkan kinerja karena kenyamanan selama menjalankan tugas-tugasnya membuat produktivitas pegawai meningkat. Faktor lingkungan kerja berperan penting dalam mewujudkan tujuan organisasi.

Keterkaitan interaksi hubungan antara motivasi dengan lingkungan kerja dapat dijelaskan dengan pendekatan kontijensi.Motivasi kerja merupakan dorongan di dalam diri pegawai yang menghasilkan suatu sikap untuk mengerahkan seluruh kemampuan dalam mencapai tujuan organisasi.Munparidi (2012) menyatakan lingkungan kerja berpengaruh signifikan terhadap kinerja karyawan.Hasilnya penelitiannya berbeda dengan Sukmasari (2011) mengatakan bahwa lingkungan kerja tidak berpengaruh terhadap kinerja pegawai.Perbedaan hasil penelitian solusinya adalah melalui pendekatan kontijensi (contingency approach) (Govindarajan, 1988).Motivasi merupakan salah satau varibel moderasi yang dapat memperkuat atau memperlemah pengaruh lingkungan kerja pada kinerja pegawai.Organisasi dapat dengan tepat melakukan tindakan yang terkait dengan motivasi yang pada akhirnya dicapai dalam pencapaian tujuan organisasi.Pendekatan ini dipakai untuk semua pengetahuan yang mutakhir tentang organisasi dengan cara yang paling tepat, karena tindakan yang tepat 
bergantung pada variabel situasional (Davis dan Newstrom, 1985). Pendekatan kontijensi ini mempunyai pandangan bahwa hubungan antara variabel bebas dengan varibel terikat dipengaruhi oleh variabel yang bersifat kondisional, seperti motivasi.Berdasarkan penjabaran diatas dibuatlah suatu hipotesis:

$\mathrm{H}_{3}$ : Motivasi memperkuat pengaruh lingkungan kerja pada kinerja Bendahara Desa di Kabupaten Tabanan.

\section{METODE PENELITAN}

Kinerja Bendahara Desa 2015 yang masih rendah disertai dengan adanya LHP ITPROV dan temuan BPK RI menjadikan lokasi penelitian dilakukan pada seluruh desa di Kabupaten Tabanan. Kinerja Bendahara Desa di desa-desa Kabupaten Tabanan dijadikan ruang lingkup oleh peneliti. Sugiyono(2013:59) menerangkan variabel Independen (bebas) adalah variabel yang dapat menyebaban terjadinya perubahan pada variabel dependen (terikat).Penelitian ini menjabarkan varibel bebas menjadi kompetensi $\left(\mathrm{X}_{1}\right)$, kepemimpinan $\left(\mathrm{X}_{2}\right)$ dan lingkungan kerja $\left(\mathrm{X}_{3}\right)$.Kompetensi merupakan keahlian yang dimiliki dalam melakukan tugas yang diberikan agar dapat memuaskan ditempat kerjanya.Indikator variabel kompetensi $\left(\mathrm{X}_{1}\right)$ dijabarkan menjadi tiga yaitu; indikator pendidikan, pengalaman dan pelatihanyang dikembangkan oleh Adnan (2012). Variabel kompetensi diuraikan menjadi 9 pertanyaan.Kepemimpinan merupakan seni mempengaruhi orang maupun bawahannya disertai komunikasi yang baik dan efektif agar dapat menyamakan visi dan misi demi tercapainya tujuan organisasi. Variabel kepemimpinan $\left(\mathrm{X}_{2}\right)$ dengan empat indikator yang dikembangkan oleh Herawati (2009) yaitu pemimpin sebagai inovator, pemimpin sebagai komunikator, pemimpin sebagai motivator dan pemimpin sebagai 
kontroler. Variabel kepemimpinan diuraiakan dalam 11 pertanyaan. Lingkungan kerja adalah segala sesuatu yang ada di sekitar pekerja yang dapat memengaruhi dalam menjalankan tugas-tugas yang dibebankan. Variabel lingkungan kerja $\left(\mathrm{X}_{3}\right)$ dengan tiga indikator yang dikembangan Rustini (2009) yaitu kondisi fisik kerja, hubungan kerja serta pola komunikasi. Varibel lingkungan kerja diuraikan menjadi 8 pertanyaan.

Variabel dependen (terikat) merupakan variabel yang dipengaruhi atau menjadi akibat karena adanya variabel bebas (Sugiyono, 2013: 59). Variabel dependen dalam penelitian ini adalah kinerja Bendahara Desa di Kabupaten Tabanan selanjutnya disimbolkan dengan Y. Kinerja Bendahara Desa adalah hasil kerja Bendahara Desa dalam menatausahakan keuangan yang ada dalam tanggung jawabnya. Indikator kinerja Bendahara Desa diadopsi dari Wasasih (2015) yaitu: kemampuan, prakarsa, ketepatwaktuan, kualitas kerja dan komunikasi. Variabel kinerja diuraikan menjadi 16 pertanyaan.

Sugiyono (2013:60) menerangkan variabel moderasi adalah variabel yang dapat memperkuat atau memperlemah hubungan antara variabel bebas dan terikat. Motivasi merupakan salah satu yang dapat digunakan sebagai variabel moderasi. Motivasi ialah kemauan yang tumbuh dari diri seorang pegawai agar bisa menjalankan dan menyelesaikan tugas-tugas yang diberikan agar sesuai target yang ditetapkan. Indikator motivasi diadopsi dari Siwantara (2009) meliputikelayakan kompensasi, penghargaan atas prestasi indikator otonomi dalam pelaksanaan tugas.Variabel motivasi diuraikan menjadi 13 pertanyaan. Sugiyono (2013:115) mengungkapkan bahwa populasi merupakan wilayah 
generalisasi yang terdiri dari atas obyek dan subyek yang mempunyai kuantitas dan karakteristik tertentu yang ditetapkan oleh peneliti untuk dipelajari dan ditarik kesimpulannya. Seluruh Bendahara Desa yang ada di Kabupaten Tabanan merupakan populasi pada penelitian ini. Jumlah desa yang ada di Kabupaten Tabanan sebanyak 133 desa sehingga jumlah Bendahara Desa juga berjumlah 133 orang.

Sampel menurut Sugiyono (2013:116) adalah bagian dari jumlah dan karakteristik yang dimiliki populasi tersebut. Penelitian ini dilakukan dengan menggunakan teknik sampling jenuh yang merupakan bagian dari Nonprobability Sampling yaitu teknik pengambilan sampel yang tidak memberi peluang yang sama bagi setiap anggota populasi untuk dipilih menjadi sampel. Sampling jenuh merupakan teknik pengambilan sampel bila semua anggota populasi digunakan sebagai sampel. Istilah lain sampel jenuh adalah sensus, dimana semua anggota populasi dijadikan sampel (Sugiyono, 1999:78). Sampel dalam penelitian ini sebagai berikut:

Tabel 1

\section{Populasi Penelitian}

\begin{tabular}{llc}
\hline No & Nama Kecamatan & Jumlah Desa/Bendahara \\
\hline & & \\
1 & Baturiti & 12 \\
2 & Kediri & 15 \\
3 & Kerambitan & 15 \\
4 & Marga & 16 \\
5 & Penebel & 18 \\
6 & Tabanan & 12 \\
7 & Pupuan & 14 \\
8 & Selemadeg & 10 \\
9 & Selemadeg Barat & 11 \\
10 & Selemadeg Timur & 10 \\
Total Populasi & 133 \\
\hline
\end{tabular}

Sumber: data primer diolah, 2016. 
Data primer adalah data yang didapat langsung dari responden. Data primer dalam penelitian ini diperoleh dengan cara mengumpulkan instrumen penelitian. Sesuai dengan jenis penelitian ini adalah kuantitatif maka instrumen penelitian. dipakai untuk menjelaskan variabel yang ingin diteliti. Variabel yang hendak diteliti mempengaruhi jumlah instrumen yang dipakai. Untuk mengukur persepsi dan pendapat serta sikap individu atau kelompok mengenai fenomena sosial maka digunakan skala likert pada setiap instrumen. Indikator variabel yang dijabarkan dapat diukur denganskala likert. Penyusunan item-item dari sebuah instrumen harus didasarkan indikator. Data interval didapat melalui skala likert (Sugiyono, 2013).

Kuesioner merupakan instrumen yang dipakai pada penelitian ini.Kuesioner acuan yang dimanfaatkan adalah kuesinoer yang telah digunakan oleh peneliti sebelumnya lalu dimodifikasi dan disesuaikan agar sesuai dengan kondisi dilapangan. Instrumen perlu diadakan pengujian yang merupakan ketentuan teknis analisis agar dapat dipergunakan sebaik-baiknya. Uji reliabilitas dan uji validitas merupakan teknis analisis pengujian instrumen. Ghozali (2013:47) menjelaskan uji Reliabilitasdilakukan untuk mengetahui kehandalan atau reliabel suatu kuesioner. Kehandalan ini tercermin dari konsistennya jawaban responden terhadap suatu pertanyaan dari kuesioner yang diajukan. Uji reliabilitas dapat mengukur sebuah kuesioner yang dibuat dari penjabaran indikator jika nilai yang didapat Cronchbach's Alpha diatas 0,7 maka konstrak atau variabel tersebut dapat dinyatakan reliabel.Pengujiankedua adalah uji validitasyang bergunak untuk mengetahui sah atau tidaknya suatu alat ukur. Valid tidaknya sebuah item 
instrumen diketahui apabilakorelasi tiap faktor tersebut positif dan besarnya $>0,3$ maka instrumen tersebut memiliki validitas yang baik (Sugiyono, 2013:178).

Ujian asumsi klasik bertujuan mendeteksi ada atau tidaknya penyimpangan asumsi klasik dalam model regresi linear berganda. Pengujiandengan melakukan(a) uji Normalitas, berguna untuk melihat sebaran data populasi sudahkah terdistribusi normal. Syarat dari data populasi dinyatakan berdistribusi normal jika koefisien Asyum Sig (2-tailed)> alpha $=0,005$, (b) uji Heteroskedastisitas, untuk mengetahui perbedaan varians dari residual dari pengamatan satu ke pengamatan lain. Gejala heteroskedastisitas tidak terjadi bila nilai signifikansi $t_{\text {hitung }}$ dari semua variabel lebih besar dari alpa $(0,05)$ dan (c) uji Multikolinearitas, dilakukan untuk melihat hubungan atau korelasi pada variabel bebas. Terjadinya multikolinieritas adalah jika nilai tolerance $\leq 0,10$ atau sama dengan nilai $\mathrm{VIF} \geq 10$. Model yang baik adalah tidak terjadinya multikolinearitas. Untuk mengetahui interaksi motivasi dengan kompetensi, kepemimpinan dan lingkungan kerja terhadap pengaruh kinerja Bendahara Desa maka menggunakan alat bantu komputer program Statistical Package for Social Scince(SPSS). Analisis regresi moderasi atau Moderated Regression Analisis (MRA)adalah merupakan aplikasi khusus regresi linier berganda dimana dalam persamaan regresinya mengandung unsur interaksi (Ghozali, 2006). Model persamaan linier pada penelitian ini dirumuskan:

$$
\left.Y=\alpha+\beta_{1} X_{1}+\beta_{2} X_{2}+\beta_{3} X_{3}+\beta_{4} X_{4} X_{1}+\beta_{5} X_{4} X_{2} \beta_{6} X_{4} X_{3}+\ldots \ldots \ldots \ldots \ldots \ldots . . .1\right)
$$


Keterangan :

$\mathrm{Y}=$ Kinerja Bendahara Desa

$\alpha=$ Konstanta

$\mathrm{X}_{1}=$ Kompetensi

$\mathrm{X}_{2}=$ Kepemimpinan

$\mathrm{X}_{3}=$ Lingkungan Kerja

$\mathrm{X}_{4}=$ Motivasi

$\beta_{1}, \beta_{2}, \beta_{3}, \beta_{4}=$ Koefisien Regresi

$\mathrm{e}=$ error

\section{HASIL DAN PEMBAHASAN}

Pengujian terhadap kelayakan instrumen penelitian yang digunakan dilakukan dengan uji reliabilitas dan validitas. Berdasarkan Tabel 2 menunjukkan bahwa instrumen pada tiap-tiap variabel adalah valid atau handal hal ini dilihat dari nilai pearson correlation pada tiap instrumen diatas 0,30 sehingga mampu digunakan untuk menguji hipotesis penelitian.

Tabel 2

Hasil Uji Validitas

\begin{tabular}{|c|c|c|c|}
\hline Variabel & $\begin{array}{c}\text { Kode } \\
\text { Instrumen } \\
\end{array}$ & $\begin{array}{l}\text { Nilai Pearson } \\
\text { Correlation }\end{array}$ & Keterangan \\
\hline \multirow{9}{*}{ Kompetensi $\left(\mathrm{X}_{1}\right)$} & $\mathrm{X}_{1.1}$ & 0,795 & valid \\
\hline & $\mathrm{X}_{1.2}$ & 0,858 & valid \\
\hline & $\mathrm{X}_{1.3}$ & 0,718 & valid \\
\hline & $\mathrm{X}_{1.4}$ & 0,868 & valid \\
\hline & $\mathrm{X}_{1.5}$ & 0,836 & valid \\
\hline & $\mathrm{X}_{1.6}$ & 0,825 & valid \\
\hline & $\mathrm{X}_{1.7}$ & 0,760 & valid \\
\hline & $\mathrm{X}_{1.8}$ & 0,851 & valid \\
\hline & $\mathrm{X}_{1.9}$ & 0,750 & valid \\
\hline \multirow[t]{11}{*}{ Kepemimpinan $\left(\mathrm{X}_{2}\right)$} & $\mathrm{X}_{2.1}$ & 0,891 & valid \\
\hline & $\mathrm{X}_{2.2}$ & 0,893 & valid \\
\hline & $\mathrm{X}_{2.3}$ & 0,827 & valid \\
\hline & $\mathrm{X}_{2.4}$ & 0,928 & valid \\
\hline & $\mathrm{X}_{2.5}$ & 0,903 & valid \\
\hline & $\mathrm{X}_{2.6}$ & 0,793 & valid \\
\hline & $\mathrm{X}_{2.7}$ & 0,861 & valid \\
\hline & $\mathrm{X}_{2.8}$ & 0,893 & valid \\
\hline & $\mathrm{X}_{2.9}$ & 0,916 & valid \\
\hline & $\mathrm{X}_{2.10}$ & 0,921 & valid \\
\hline & $\mathrm{X}_{2.11}$ & 0,863 & valid \\
\hline Lingkungan & $\mathrm{X}_{3.1}$ & 0,697 & valid \\
\hline $\operatorname{Kerja}\left(X_{3}\right)$ & $\mathrm{X}_{3.2}$ & 0,844 & valid \\
\hline
\end{tabular}




\begin{tabular}{|c|c|c|c|}
\hline & $\mathrm{X}_{3.3}$ & 0,787 & valid \\
\hline & $\mathrm{X}_{3.4}$ & 0,915 & valid \\
\hline & $\mathrm{X}_{3.5}$ & 0,934 & valid \\
\hline & $\mathrm{X}_{3.6}$ & 0,904 & valid \\
\hline & $\mathrm{X}_{3.7}$ & 0,921 & valid \\
\hline & $\mathrm{X}_{3.8}$ & 0,910 & valid \\
\hline \multirow[t]{13}{*}{ Motivasi $\left(\mathrm{X}_{4}\right)$} & $\mathrm{X}_{4.1}$ & 0,711 & valid \\
\hline & $\mathrm{X}_{4.2}$ & 0,810 & valid \\
\hline & $\mathrm{X}_{4.3}$ & 0,816 & valid \\
\hline & $\mathrm{X}_{4.4}$ & 0,803 & valid \\
\hline & $\mathrm{X}_{4.5}$ & 0,592 & valid \\
\hline & $\mathrm{X}_{4.6}$ & 0,852 & valid \\
\hline & $\mathrm{X}_{4.7}$ & 0,811 & valid \\
\hline & $\mathrm{X}_{4.8}$ & 0,858 & valid \\
\hline & $\mathrm{X}_{4.9}$ & 0,854 & valid \\
\hline & $\mathrm{X}_{4.10}$ & 0,836 & valid \\
\hline & $\mathrm{X}_{4.11}$ & 0,817 & valid \\
\hline & $\mathrm{X}_{4.12}$ & 0,888 & valid \\
\hline & $\mathrm{X}_{4.13}$ & 0,880 & valid \\
\hline Kinerja & $\mathrm{Y}_{.1}$ & 0,461 & valid \\
\hline Bendahara & $\mathrm{Y}_{.2}$ & 0,800 & valid \\
\hline \multirow[t]{14}{*}{ Desa (Y) } & $\mathrm{Y}_{.3}$ & 0,818 & valid \\
\hline & $\mathrm{Y}_{.4}$ & 0,622 & valid \\
\hline & $\mathrm{Y}_{.5}$ & 0,842 & valid \\
\hline & $\mathrm{Y}_{.6}$ & 0,789 & valid \\
\hline & $\mathrm{Y}_{.7}$ & 0,789 & valid \\
\hline & $\mathrm{Y}_{.8}$ & 0,890 & valid \\
\hline & $\mathrm{Y}_{.9}$ & 0,911 & valid \\
\hline & $Y_{.10}$ & 0,756 & valid \\
\hline & $Y_{.11}$ & 0,426 & valid \\
\hline & $\mathrm{Y}_{.12}$ & 0,874 & valid \\
\hline & $Y_{.13}$ & 0,736 & valid \\
\hline & $\mathrm{Y}_{.14}$ & 0,643 & valid \\
\hline & $\mathrm{Y}_{.15}$ & 0,850 & valid \\
\hline & $Y_{.16}$ & 0,709 & valid \\
\hline
\end{tabular}

Sumber : data primer diolah, 2016.

Tabel 3 menyajikan hasil uji reliabilitas instrumen pada setiap variabel.

Nilai Alpha Cronbanch> 0,7 pada setiap variabel mencerminkan instrumen dalam penelitian ini dikatakan handal atau reliabel.

Tabel 3

Hasil Uji Reliabilitas Instrumen

\begin{tabular}{lccl}
\hline \multicolumn{1}{c}{ Variabel } & $\begin{array}{c}\text { Jumlah } \\
\text { Item }\end{array}$ & $\begin{array}{c}\text { Cronbach's } \\
\text { alpha }\end{array}$ & Keterangan \\
\hline Kompetensi $\left(\mathrm{X}_{1}\right)$ & 9 & 0,932 & Reliabel \\
Kepemimpinan $\left(\mathrm{X}_{2}\right)$ & 11 & 0,971 & Reliabel \\
Lingkungan Kerja $\left(\mathrm{X}_{3}\right)$ & 8 & 0,952 & Reliabel \\
Motivasi $\left(\mathrm{X}_{4}\right)$ & 14 & 0,957 & Reliabel \\
Kinerja $(\mathrm{Y})$ & 16 & 0,949 & Reliabel \\
\hline
\end{tabular}


Sumber : data primer diolah, 2016.

Tabel 4

Hasil Analisis Moderasi

\begin{tabular}{|c|c|c|c|c|c|}
\hline \multirow[b]{2}{*}{ Variabel } & \multicolumn{2}{|c|}{$\begin{array}{l}\text { Unstandaridized } \\
\text { Coefficients }\end{array}$} & \multicolumn{3}{|c|}{$\begin{array}{l}\text { Standardized } \\
\text { Coefficients }\end{array}$} \\
\hline & $\mathrm{B}$ & Std. Error & Beta & $\mathrm{t}$ & sig \\
\hline (Constant) & 5,735 & 3,518 & & 1,630 & 0,106 \\
\hline Kompetensi $\left(\mathrm{X}_{1}\right)$ & 0,952 & 0,409 & 0,610 & 2,325 & 0,022 \\
\hline Kepemimpinan $\left(\mathrm{X}_{2}\right)$ & $-0,159$ & 0,263 & $-0,125$ & $-0,607$ & 0,545 \\
\hline Lingkungan Kerja $\left(\mathrm{X}_{3}\right)$ & 0,728 & 0,369 & 0,417 & 1,973 & 0,051 \\
\hline Motivasi $\left(\mathrm{X}_{4}\right)$ & 0,189 & 0,135 & 0,156 & 1,406 & 0,162 \\
\hline $\mathrm{X}_{1 \_} \mathrm{X}_{4}$ & $-0,008$ & 0,009 & $-0,317$ & $-0,881$ & 0,380 \\
\hline $\mathrm{X}_{2} \mathrm{X}_{4}$ & 0,014 & 0,006 & 0,628 & 2,218 & 0,035 \\
\hline $\mathrm{X}_{3 \_} \mathrm{X}_{4}$ & $-0,011$ & 0,009 & $-0,377$ & $-1,228$ & 0,222 \\
\hline $\mathrm{F}$ & 53,570 & & & & \\
\hline Sig F & 0,000 & & & & \\
\hline R Square & 0,761 & & & & \\
\hline Adjusted R Square & 0,746 & & & & \\
\hline
\end{tabular}

Berdasarkan Tabel 4 didapat persamaan regresinya sebagai berikut:

$$
\begin{aligned}
& Y=5,735+0,952 X_{1}-0,159 X_{2}+0,728 X_{3}-0,008 X_{1} \_X_{4}+ \\
& 0,014 X_{2} X_{4}-0,011 X_{1} X_{4}+e
\end{aligned}
$$

Nilai konstanta $(\alpha)$ adalah 5,735 dengan nilai signifikansi 0,106 diatas alpha $=0,05$ artinya apabila variabel kompetensi, kepemimpinan, lingkungan kerja, motivasi dan interaksi antara variabel indenpenden dengan moderasi (moderasi1, moderasi2, moderasi3) adalah nol maka variabel kinerja Bendahara Desa hasilnya nihil. Koefisien regresi kompetensi $\left(\mathrm{X}_{1}\right)$ adalah 0,952dengan nilai signifikansi sebesar 0,022, jikakompetensi $\left(\mathrm{X}_{1}\right)$ naik sebesar 1 satuan, maka variabel kinerja akan meningkat sebesar 0,952 (secara statistik) dengan asumsi variabel lainnya konstan. Koefisien regresi kepemimpinan $\left(\mathrm{X}_{2}\right)$ adalah $-0,159$ dengan tingkat signifikansi sebesar 0,545 lebih besar dari $\alpha=0,05$ yang berarti variabel 
kepemimpinan $\left(\mathrm{X}_{2}\right)$ tidak mampu meningkatkan kinerja Bendahara Desa di Kabupaten Tabanan (Y). Koefisien regresi lingkungan kerja $\left(\mathrm{X}_{3}\right)$ adalah 0,728 dan nilai signifikansi adalah 0,051 diatas $\alpha=0,05$ berarti variabel lingkungan kerja $\left(X_{3}\right)$ tidak mampu meningkatkan kinerja Bendahara Desa di Kabupaten Tabanan (Y).

Koefisien regresi variabel interaksi antara kompetensi dengan motivasi $\left(\mathrm{X}_{1_{-}}\right.$ $\mathrm{X}_{4}$ ) sebesar $-0,008$ dan nilai signifikansi 0,380 diatas dari $\alpha=0,05$ artinya variabel motivasi tidak mampu memoderasi pengaruh variabel kompetensi pada kinerja Bendahara Desa di Kabupaten Tabanan (Y), sehingga hasil ini menolak $\mathrm{H}_{1}$. Koefisien regresi variabel interaksi antara kepemimpinan dengan motivasi $\left(\mathrm{X}_{2}\right.$ $\mathrm{X}_{4}$ ) sebesar 0,014 dan nilai signifikansi 0,035 dibawah $\alpha=0,05$ artinya variabel motivasi $\left(\mathrm{X}_{4}\right)$ mampu memperkuat pengaruh variabel kepemimpinan $\left(\mathrm{X}_{4}\right)$ pada kinerja Bendahara Desa di Kabupaten Tabanan (Y) sehingga $\mathrm{H}_{2}$ diterima. Nilai koefisien regresi variabel interaksi antara lingkungan kerja dengan motivasi $\left(\mathrm{X}_{3}\right.$ $\mathrm{X}_{4}$ ) sebesar $-0,011$ dan nilai signifikansi 0,222 diatas $\alpha=0,05$ artinya variabel motivasi $\left(\mathrm{X}_{4}\right)$ tidak mampu memoderasi pengaruh variabel lingkungan kerja $\left(\mathrm{X}_{3}\right)$ pada kinerja Bendahara Desa di Kabupaten Tabanan (Y), sehingga hasil ini menolak $\mathrm{H}_{3}$.

Uji kelayakan model (Goodness of Fit) dapat melihat apakah model regresi yang digunakan layak (fit) atau tidak. Uji $\mathrm{F}$ digunakan untuk menguji apakah variabel bebas $(\mathrm{X})$ memiliki pengaruh terhadap variabel terikat $(\mathrm{Y})$. Berdasarkan Tabel 4, nilai uji $\mathrm{F}$ adalah 53,570 dan nilai signifikansi 0,000 dibawah nilai dari nilai signifikansi yaitu $\alpha=0,05$. Berdasarkan nilai uji $F$ diatas menyatakan model penelitian yang dipakai adalah layak serta pengujian hipotesis dapat diteruskan. 
Besarnya nilai koefisien determinasi ditunjukkan oleh nilai Adjusted $R$ Square sebesar 0,746. Hal ini berarti 74,6 persen variabel kinerja Bendahara Desa mampu dijelaskan oleh variabel kompentensi, kepemimpinan, lingkungan kerja, interaksi kompetensi dengan motivasi, interaksi kepemimpinan dengan motivasi dan interaksi lingkungan kerja dengan motivasi, sedangkan sisanya sebesar 25,4 persen dijelaskan oleh faktor-faktor lain yang tidak dijelaskan dalam model. Berdasarkan hasil pengujian hipotesis menunjukkan bahwa motivasi mampu memperkuat pengaruh kepemimpinan pada kinerja Bendahara Desa di Kabupaten Tabanan, motivasi tidak mampu memoderasi pengaruh kompetensi pada kinerja Bendahara Desa di Kabupaten Tabanan dan motivasi tidak mampu memoderasi pengaruh lingkungan kerja pada kinerja Bendahara Desa di Kabupaten Tabanan.

Berdasarkan Tabel 4, ketika motivasi berinteraksi dengan kompetensi pada kinerja Bendahara Desa dapat dilihat nilai koefisien $\beta$ adalah $-0,008$ dengan nilai signifikansi $0,380>\alpha=0,05$. Hal ini menunjukkan bahwa motivasi tidak mampu memoderasi pengaruh kompetensi pada kinerja Bendahara Desa Kabupaten Tabanan sehingga hipotesis pertama ditolak.Motivasi merupakan daya pendorong individu untuk melaksanakan suatu tindakan tertentu atau menimbulkan semangat kerja. Menurut teori dua faktor dari Herzberg yang membagi motivasi menjadi dua faktor yaitu : (1) Hygeine factor (eksternal) seperti gaji, kehidupan pribadi, kualitas supervisi, kondisi kerja, jaminan kerja, hubungan antar pribadi, kebijaksanaan dan administrasi perusahaan; (2) Motivation factors (internal), yang dikaitkan dengan isi pekerjaan mencakup keberhasilan, pengakuan, peningkatan dan pertumbuhan dalam pekerjaan. Penelitian ini menunjukkan 
bahwa kompetensi yang dimiliki oleh Bendahara Desa di Kabupaten Tabanan ketika berinteraksi dengan variabel motivasi tidak mampu meningkatkan kinerja Bendaharara Desa.

Kompetensi seorang Bendahara Desa di Kabupaten Tabanan dipengaruhi oleh pengalaman kerja dan keterampilan yang dimiliki hal ini dapat dilihat dari lama masa kerja yaitu diatas 5 tahun yang berpengaruh pada kinerja yang dihasilkan. Tabel 5.8 menunjukkan bahwa salah satu indikator motivasi yaitu kelayakan kompensasi dinilai tidak baik oleh responden yang dapat menurunkan motivasi. Kelayakan kompensasi dirasakan sebagai motivasi dalam bekerja, menurunnya motivasi akibat tidak baiknya kompensasi tidak dapat meningkatkan kompetensi yang dimiliki oleh Bendahara Desa yang berpengaruh pada kinerja Bendahara Desa di Kabupaten Tabanan.

Hipotesis kedua $\left(\mathrm{H}_{2}\right)$ menyatakan bahwa motivasi mampu memperkuat pengaruh kepemimpinan pada kinerja Bendahara Desa. Berdasarkan Tabel 4 dapat dilihat saat interaksi motivasi dengan kepemimpinan pada kinerja Bendahara Desa didapat koefisien $\beta$ sebesar 0,014 dan nilai signifikansi $0,035<$ $\alpha=0,05$. Hal ini menunjukkan bahwa motivasi mampu memperkuat pengaruh kepemimpinan pada kinerja Bendahara Desa Kabupaten Tabanan sehingga hipotesis kedua diterima.

Kepemimpinan seorang Perbekel dalam mengelola organisasi melalui komunikasi yang baik dengan bawahan serta kemampuannya dalam memecahkan masalah yang dihadapi mampu meningkatkan kinerja Bendahara Desa. Pengaruh kepemimpinan dengan kinerja Bendahara Desa adalah tidak signifikan (Tabel 4), 
ketika berinteraksi dengan motivasi sebagai variabel pemoderasi terbukti mampu memperkuat pengaruh kepemimpinan pada kinerja Bendahara Desa di Kabupaten Tabanan. Indikator motivasi seperti pengakuan prestasi dan otonomi dalam melaksanakan tugas dapat memperkuat pengaruh kepemimpinan sehingga kinerja Bendahara Desa juga meningkat.

Penelitian ini konsisten dengan penelitian yang dilakukan oleh Suharyanto (2011) mengatakan bahwa secara simultan gaya kepemimpinan dan budaya organisasi berpengaruh signifikan terhadap kinerja pegawai. Ketidakkonsistenan penelitian ditunjukkan oleh penelitian Sukmasari (2011) yang menyatakan bahwa kepemimpinan tidak berpengaruh signifikan terhadap kinerja pegawai. Mujahidin (2013) menunjukkan bahwa gaya kepemimpinan tidak berpengaruh positif terhadap kinerja karyawan sedangan motivasi berpengaruh positif terhadap kinerja karyawan.

Hipotesis ketiga $\left(\mathrm{H}_{3}\right)$ menyatakan bahwa motivasi mampu memperkuat pengaruh lingkungan kerja pada kinerja Bendahara Desa di Kabupaten Tabanan. Berdasarkan Tabel 5.14 Diketahui interaksi motivasi dengan lingkungan kerja pada kinerja Bendahara Desa memiliki koefisien $\beta$ sebesar -0,011 dengan tingkat signifikansi $0,222>\alpha=0,05$. Hal ini menunjukkan bahwa motivasi tidak mampu memoderasi pengaruh lingkungan kerja pada kinerja Bendahara Desa Kabupaten Tabanan sehingga hipotesis ketiga ditolak.

Lingkungan kerja adalah segala sesuatu yang ada disekitar pekerja yang dapat memengaruhi dalam menjalankan tugas yang dibebankan (Nitisemito, 2002). Keseharian waktu pegawai dihabiskan di tempat bekerja, kenyamanan 
dalam bekerja berpengaruh pada kinerja yang dihasilkan. Lingkungan kerja yang dimaksud antara lain, uraian jabatan yang jelas, target kerja, pola komunikasi kerja yang efektif, iklim kerja dan fasilitas kerja yang relatif memadai (Mangkunegara, 2006: 17). Fasilitas kerja yang didapat relatif memadai guna mendukung kelancaran seorang Bendahara Desa dalam bekerja.

Lingkungan kerja dalam penelitian ini dijelaskan dalam indikatornya seperti kondisi fisik kerja, hubungan kerja dan komunikasi yang baik berpengaruh pada kinerja Bendahara Desa di Kabupaten Tabanan. Motivasi sebagai variabel moderasi merupakan dorongan di dalam diri pegawai yang menghasilkan suatu sikap untuk mengerahkan seluruh kemampuan dalam mencapai tujuan organisasi. Rendahnya penilaian responden terhadap tunjangan yang diterima oleh Bendahara Desa. Ketidaklayakan penghasilan yang diterima menurunkan motivasi sehingga tidak dapat memperkuat hubungan lingkungan kerja pada kinerja Bendahara Desa di Kabupaten Tabanan. Penelitian ini menunjukkan variabel motivasi tidak mampu memoderasi pengaruh lingkungan kerja pada kinerja Bendahara Desa di Kabupaten Tabanan.

Penelitian ini konsisten dengan penelitian yang dilakukan oleh Sukmasari (2012) menyatakan bahwa lingkungan kerja tidak berpengaruh terhadap kinerja pegawai sedangkan motivasi dan kepuasan kerja memiliki pengaruh signifikann terhadap kinerja pegawai. Penelitian lain yang tidak konsisten dengan penelitian ini adalah Muparidi (2012) menyatakan bahwa lingkungan kerja berpengaruh signifikan terhadap kinerja pegawai. 


\section{SIMPULAN DAN SARAN}

Berdasarkan hasil analisis dan pembahasan pada bab sebelumnya dapat disimpulkan bahwa: (1)Motivasi tidak memperkuat pengaruh kompetensi pada kinerja Bendahara Desa. Motivasi sebagai dorongan dalam bekerja ketika berinteraksi dengan kompetensi tidak mampu meningkatkan kinerja Bendahara Desa di Kabupaten Tabanan;(2)Motivasi memperkuat pengaruh kepemimpinan pada kinerja Bendahara Desa. Variabel kepemimpinan dapat diperkuat oleh variabel motivasi yang berpengaruh pada kinerja Bendahara Desa di Kabupaten Tabanan; (3) Motivasi tidak memperkuat pengaruh lingkungan kerja pada kinerja Bendahara Desa. Lingkungan kerja tidak berpengaruh terhadap kinerja Bendahara Desa di Kabupaten Tabanan, ketika berinteraksi dengan motivasi ternyata tidak mampu meningkatkan kinerja Bendahara Desa di Kabupaten Tabanan.

Peneliti menyampaikan beberapa saran yang diperlukan terkait dengan kinerja Bendahara Desa antara lain(1) Penelitian selanjutnya dapat menggunakan penelitian ini sebagai salah satu referensi mengenai topik yang serupa pada kinerja Bendahara Desa pada seluruh desa se-Provinsi Bali;(2) Hasil R square sebesar 0,746 atau $74,6 \%$ variabel kinerja Bendahara Desa dipengaruhi oleh variabel bebas dalam penelitian ini dan sisanya sebesar $25,4 \%$ dijelaskan oleh variabel diluar model. Peneliti selanjutnya dapat menambahkan variabel lain yang diduga berpengaruh langsung maupun tidak langsung pada kinerja Bendahara Desa seperti budaya organisasi dan komitmen organisasi;(3) Hasil regresi moderasi menunjukkan bahwa motivasi tidak mampu memoderasi variabel kompetensi dan 
lingkungan kerja pada kinerja Bendahara Desa di Kabupaten Tabanan, hal ini diduga ada variabel lain yang mampu memoderasi kompetensi, kepemimpinan dan lingkungan kerja, peneliti selanjutnya dapat menemukan variabel lain untuk mendapatkan hasil yang lebih baik; (4) Untuk mendapatkan kinerja Bendahara Desa yang lebih baik Pemerintah Kabupaten Tababanan diharapkan dapat memberikan pelatihan dan sosialisasi tentang perbendaharaan secara berkelanjutan, memperhatikan pendidikan formal seorang Bendahara Desa serta memberikan kelayakan kompensasi bagi Bendahara Desa agar sesuai dengan beban kerja yang kini ditanggungnya, meningkatkan jumlah dan kualitas peralatan kantor yang digunakan agar sesuai dengan kebutuhan, seorang Perbekel agar memberian penjelasan yang mudah dipahami bagi bawahannya sehingga mampu meningkatkan motivasi Bendahara Desa untuk berkinerja lebih baik lagi.

\section{REFERENSI}

Ghozali, Imam. 2006. Aplikasi Analisis Multivatiate Dengan Program SPSS. Cetakan Keempat. Semarang. Badan Penerbit Universitas Diponegoro.

Ghozali, Imam. 2013. Aplikasi Analisis Multivatiate Dengan Program IBM SPSS 21. Edisi Ketujuh. Semarang. Badan Penerbit Universitas Diponegoro.

Govindarajan, V. 1988.A Contigency Approach to Strategy Implementation at the Business-Unit Level Integrating Administrative Mechanism with Strategy.Academy of Management Journal, 31 (4): 828-851.

Herawati, Dewa Ayu. 2009. Pengaruh Kompensasi, Kepemimpinan, dan Lingkungan Kerja Terhadap Kinerja Pegawai Lembaga Penjaminan Mutu Pendidikan Bali. (tesis). Denpasar: Universitas Udayana.

Irwan, D. 2011. "Pengaruh Penerapan Sistem Pengendalian Intern Pemerintah, Kompetensi Sumber Daya Manusia dan Penerapan Standar Akuntansi Pemerintahan terhadap Kualias Laporan Keuangan Pemerintah Provinsi Sumatera Barat”. (tesis). Universitas Gajahmada. 
Jankingthong, K., and Rurkhum, S. 2012. Factors Affecting job performance "A Review literature.Journal of social science, humanities and art, 12(2): 115127.

Joseph, EE., Winston, BE. 2005. A Correlation of Servant Leadership, Leader Trust and Organizational Trust. Leadersh, Organ. Dev. J., 26(1): 6-22.

Kusuma, E.A.I.G. 2013. Pengaruh Kejelasan Anggaran, Komitmen Organisasi dan Ketidakpastian Lingkungan pada Ketepatan Anggaran (Studi Empiris di SKPD Pemerintah Provinsi Bali). (tesis). Denpasar: Universitas Udayana.

Locke, E.A.1968. Toward A Theory of Task Motivation and Incentives. American Institute of Research, 16 (3): 157-89.

Mathison, David L., and Vinja,Vils N., 2010. The Annual Performance Review As a Positive Source For Employee Motivation?.Journal of Business \& Economic Research, 8 (12): 111-120.

Mitchel, T. R. And Larson, J.R. (Eds). 1987. People in Organizations: An Introduction to Organizational Behaviour. New Yor: McGraw-Hill.

Mujahidin. 2013. Pengaruh Gaya Kepemimpina, Motivasi dan Pelatihan terhadap Kinerja Karyawan Dinas Pekerjaan Umum Kabupaten Sintang. Jurnal Manajemen dan Bisnis, 1(1).

Munparidi. 2012. Pengaruh Kepemimpinan, Motivasi, Pelatihan, dan Lingkungan Kerja terhadap Kinerja Karyawan pada Perusahaan Daerah Air Minum Tirta Musi Kota Palembang. Jurnal Orasi Bisnis Edisi e-VII, 1 (2): 47-53.

Long, C. S., \& Thean, L. Y. 2012. Employees Turnover Intention: A Leadership Issue? International Journal of Future and Communicatioan, 1(3): 229-230.

Nitisemito, A. S. 2002. Manajemen Personalia. Edisi Revisi. Ghalia, Jakarta.

Parkinson, J. 2012. Accounting for Process Cost System in New Zeland.The Journal of Law and Financial Manajement.11 (2).

Peraturan Menteri Dalam Negeri Nomor 113 Tahun 2014 tentang Pengelolaan Keuangan Desa.

Prayitno, Widodo dan Suprapto.2002. Standarisasi Kompetensi Pegawai Negeri Sipil Menuju Era Globalisasi Global.Seri Kertas Kerja Volume II Nomor 05. Jakarta. Pusat Penelitian dan Pengembangan BKN. 
Rahman, dkk.2014. Pengaruh Kompetensi dan Kepemimpinan terhadap Kinerja Karyawan dengan Motivasi sebagai Variabel Intervening (Studi Kasus pada Karyawan Bagian Pabrik PT. Jember Indonesia). Artikel Ilmiah Remaja 2014.

Ramlall, Sunil. J., 2006.Identifying and Understanding HR Competencies and Their Relationship to Organizational Practices.Applied H.R.M. Research.11 (1): 27-38.

Robbin, S.P., Judge, T.A. 2008. Organizational Behavior. 12 th Edition, Jakarta: Salemba Empat.

Rustini, N.K.A. 2015.Pengaruh Kompensasi dan Lingkungan Kerja pada Komitmen Organisasi dan Implikasinya pada Kinerja Pengelola Anggaran. (tesis). Denpasar: Universitas Udayana.

Sedarmayanti.2001. Sumber Daya Manusia dan Produktivitas Kerja.Mandar Maju, Bandung.

Siwantara.2009. Pengaruh Kompentensi Profesional dan Motivasi Kerja serta Iklim Organisasi terhadap Disiplin Kerja dan Kinerja Dosen Politeknik Negeri Bali. (tesis). Denpasar: Universitas Udayana.

Spencer, L.M and Spencer, S.G. 1993. Competence at work Models for superior performance. New York. Wiley.

Suarya, I.N.C. 2010. Pengaruh Kompensasi, Pelatihan, Kepemimpinan, dan Lingkungan Kerja pada Kinerja Pengelolaan Anggaran Pemerintah Kabupaten Tabanan. (tesis). Denpasar: Universitas Udayana.

Sudarmanto. 2009. Kinerja dan Pengembangan Kompetensi SDM. Yogyakarta: Pustaka Pelajar.

Sugiyono. 1999. Metode Penelitian Bisnis. Bandung. CV. Alfabeta.

Sugiyono. 2013. Metode Penelitian Bisnis (Pendekatan Kuantitatif, Kualitatif dan R\&D). Bandung. CV. Alfabeta.

Suharyanto.2011. Pengaruh Gaya Kepemimpinan dan Budaya Organisasi terhadap Kinerja Pegawai di Universitas PGRI Adi Buana Surabaya. (tesis). Surabaya; Universitas Narotama Surabaya.

Sukmasari, Hentry. 2011. Pengaruh Kepemimpinan, Motivasi, Insentif, Lingkungan Kerja, dan Kepuasan Kerja terhadap Kinerja Pegawai Dinas Pengelolaan Keuangan dan Aset Daerah Kota Semarang.(tesis). Semarang: Universitas Dian Nuswantoro. 
Sultana, et al. 2012. Impact of Training on Employee Performance: A Study of Telecommunication Sector in Pakistan. Interdisciplinary journal of contemporary research in business. 4 (6): 646-661.

Suryadana, dkk. 2014. Pengaruh Kepemimpinan, Kompetensi dan Kompensasi terhadap Kinerja Pegawai pada Dinas Pertanian Tanaman Pangan Provinsi Jawa Barat. Jurnal Ekonomi, Bisnis dan Entrepreneurship. 8(1):27-39.

Suryantari, E.P. 2012. Pengaruh Kompensasi, Lingkungan Kerja dan Motivasi pada Kinerja Pengelolaan Anggaran Belanja Universitas Udayana. (tesis). Denpasar: Universitas Udayana.

Taiwo, AS. 2010. The Influence of Work Enviroment on Workers Productivity: A Case of Selected Oil and Gases Industry in Lagos, Nigeria. Afri. J. Bus Manage., 4 (3): 299-307.

Thao, et al. 2015. Factors Affecting Employee Performance-Evidence From Petrovietnam Engineering Consultancy. 1-13.

Undang-undang Nomor 6 Tahun 2014 tentang Desa.

Wahyuni, Evi. 2015. Pengaruh Budaya Organisasi dan Gaya Kepemimpinan terhadap Kinerja Pegawai Bagian Keuangan Organisasi Sektor Publik dengan Motivasi Kerja sebagai Variabel Intervening.Jurnal Nominal.4 (1).

Widiastuti. 2007. Pengaruh Gaya Kepemimpinan dan Partisipasi terhadap Efektivitas Kinerja Dinas Pariwisata Kota Denpasar. (tesis). Denpasar: Universitas Udayana.

Widodo.2013. Analisis Pengaruh antara Faktor Pendidikan, Motivasi dan Budaya Kerja Terhadap Kinerja Pegawai dalam Pelaksanaan Pelayanan Publik (Studi Kasus pada Badan Pelayanan Perijinan Terpadu Kota Pontianak), (tesis). Pontianak: Universitas Tanjungpura.

Wirama, M.I.G.P. 2010. Pengaruh Tingkat Pendidikan, Masa Kerja dan Pengetahuan Akuntansi pada Kinerja Pejabat Penatausahaan Keuangan Satuan Kerja Perangkat Daerah Kabupaten Tabanan. (tesis).Denpasar: Universitas Udayana. 